
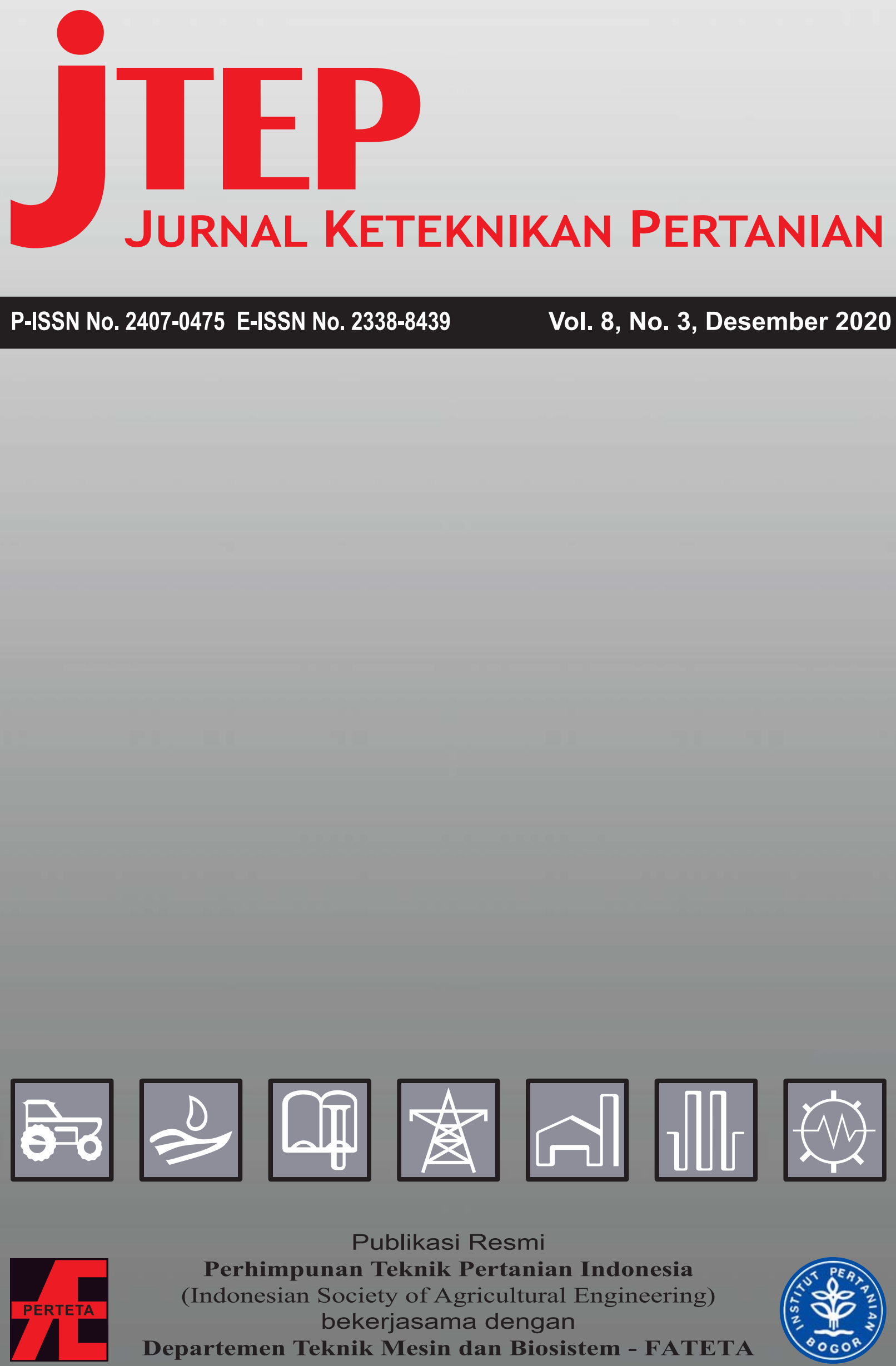

\footnotetext{
Publikasi Resmi

Perhimpunan Teknik Pertanian Indonesia (Indonesian Society of Agricultural Engineering) bekerjasama dengan Departemen Teknik Mesin dan Biosistem - FATETA Institut Pertanian Bogor
}

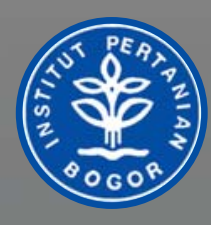




\section{jTEP JURnal Keteknikan Pertanian}

Vol. 8, No. 3, Desember 2020

Jurnal Keteknikan Pertanian (JTEP) terakreditasi berdasarkan SK Dirjen Penguatan Riset dan Pengembangan Kementerian Ristek Dikti Nomor I/E/KPT/2015 tanggal 21 September 2015. Selain itu, JTEP juga telah terdaftar pada Crossref dan telah memiliki Digital Object Identifier (DOI) dan telah terindeks pada ISJD, IPI, Google Scholar dan DOAJ. JTEP terbit tiga kali setahun yaitu bulan April, Agustus dan Desember, Jurnal berkala ilmiah ini berkiprah dalam pengembangan ilmu keteknikan untuk pertanian tropika dan lingkungan hayati. Penulis makalah tidak dibatasi pada anggota PERTETA tetapi terbuka bagi masyarakat umum. Lingkup makalah, antara lain meliputi teknik sumberdaya lahan dan air, alat dan mesin budidaya pertanian, lingkungan dan bangunan pertanian, energi alternatif dan elektrifikasi, ergonomika dan elektronika pertanian, teknik pengolahan pangan dan hasil pertanian, manajemen dan sistem informasi pertanian. Makalah dikelompokkan dalam invited paper yang menyajikan isu aktual nasional dan internasional, review perkembangan penelitian, atau penerapan ilmu dan teknologi, technical paper hasil penelitian, penerapan, atau diseminasi, serta research methodology berkaitan pengembangan modul, metode, prosedur, program aplikasi, dan lain sebagainya. Penulisan naskah harus mengikuti panduan penulisan seperti tercantum pada website dan naskah dikirim secara elektronik (online submission) melalui http://journal.jpb.ac.id/index.php/jtep.

\section{Penanggungjawab:}

Ketua Departemen Teknik Mesin dan Biosistem, Fakultas Teknologi Pertanian,IPB

Ketua Perhimpunan Teknik Pertanian Indonesia

\section{Dewan Redaksi:}

Ketua : Yohanes Aris Purwanto (Scopus ID: 6506369700, IPB University)

Anggota : Abdul Hamid Adom (Scopus ID: 6506600412, University Malaysia Perlis)

(editorial Addy Wahyudie (Scopus ID: 35306119500, United Arab Emirates University)

board) Budi Indra Setiawan (Scopus ID: 55574122266, IPB University)

Balasuriya M.S. Jinendra (Scopus ID: 30467710700 , University of Ruhuna)

Bambang Purwantana (Scopus ID: 6506901423, Universitas Gadjah Mada)

Bambang Susilo (Scopus ID: 54418036400, Universitas Brawijaya)

Daniel Saputera (Scopus ID: 6507392012, Universitas Sriwjaya)

Han Shuqing (Scopus ID: 55039915600, China Agricultural University)

Hiroshi Shimizu (Scopus ID: 7404366016, Kyoto University)

I Made Anom Sutrisna Wijaya (Scopus ID: 56530783200, Universitas Udayana)

Agus Arif Munawar (Scopus ID: 56515099300, Universitas Syahkuala)

Armansyah H. Tambunan (Scopus ID: 57196349366, IPB University)

Kudang Boro Seminar (Scopus ID: 54897890200, IPB University)

M. Rahman (Scopus ID: 7404134933, Bangladesh Agricultural University)

Machmud Achmad (Scopus ID: 57191342583, Universitas Hasanuddin)

Muhammad Makky (Scopus ID: 55630259900, Universitas Andalas)

Muhammad Yulianto (Scopus ID: 54407688300, IPB University \& Waseda University)

Nanik Purwanti (Scopus ID: 23101232200, IPB University \& Teagasc Food Research Center Irlandia)

Pastor P. Garcia (Scopus ID: 57188872339 , Visayas State University)

Rosnah Shamsudin (Scopus ID: 6507783529, Universitas Putra Malaysia)

Salengke (Scopus ID: 6507093353, Universitas Hasanuddin)

Sate Sampattagul (Scopus ID: 7801640861, Chiang Mai University)

Subramaniam Sathivel (Scopus ID: 6602242315, Louisiana State University)

Shinichiro Kuroki (Scopus ID: 57052393500, Kobe University)

Siswoyo Soekarno (Scopus ID: 57200222075, Universitas Jember)

Tetsuya Araki (Scopus ID: 55628028600, The University of Tokyo)

Tusan Park (Scopus ID: 57202780408, Kyungpook National University) 


\section{Redaksi Pelaksana:}

Ketua : : Usman Ahmad (Scopus ID: 55947981500, IPB University)

Sekretaris : Lenny Saulia (Scopus ID: 16744818700, IPB University)

Bendahara : Dyah Wulandani (Scopus ID: 1883926600, IPB University)

Anggota : Satyanto Krido Saptomo (Scopus ID: 6507219391, IPB University)

Slamet Widodo (Scopus ID: 22636442900, IPB University)

Liyantono (Scopus ID: 54906200300, IPB University)

Leopold Oscar Nelwan (Scopus ID: 56088768900, IPB University)

I Wayan Astika (Scopus ID: 43461110500, IPB University)

Agus Ghautsun Niam (Scopus ID: 57205687481, IPB University)

Administrasi : Khania Tria Tifani (IPB University)

Penerbit: Departemen Teknik Mesin dan Biosistem, Institut Pertanian Bogor bekerjasama dengan Perhimpunan Teknik Pertanian Indonesia (PERTETA).

Alamat: Jurnal Keteknikan Pertanian, Departemen Teknik Mesin dan Biosistem, Fakultas Teknologi Pertanian, Kampus Institut Pertanian Bogor, Bogor 16680.

Telp. 0251-8624 503, Fax 0251-8623 026,

E-mail: jtep@apps.ipb.ac.id

Website: http://journal.ipb.ac.id/index.php/jtep

Rekening: BRI, KCP-IPB, No.0595-01-003461-50-9 a/n: Jurnal Keteknikan Pertanian

Percetakan: PT. Binakerta Makmur Saputra, Jakarta 


\section{Ucapan Terima Kasih}

Redaksi Jurnal Keteknikan Pertanian mengucapkan terima kasih kepada para Mitra Bebestari yang telah menelaah naskah pada penerbitan Vol. 8, No. 3 Desember 2020. Ucapan terima kasih disampaikan kepada: Prof.Dr.Ir. Lilik Soetiarso (Universitas Gadjah Mada), Dr.Ir. Lady Lengkey, M.Si (Universitas Sam Ratulangi), Ir. Siti Mariana Widayanti, M.Si, (Balai Besar Penelitian dan Pengembangan Pascapanen Pertanian), Dr.Ir. Lilik Pujantoro Eko Nugroho, M.Agr (Departemen Teknik Mesin dan Biosistem, IPB University), Dr.Ir. Emmy Darmawati, M. Si (Departemen Teknik Mesin dan Biosistem, IPB University), Dr. Andasuryani, S.TP, M.Si (Universitas Andalas), Ahmad Thoriq, S.TP, M.Si (Universitas Padjadjaran) 
jiep Jurnal Keteknikan Pertanian 


\title{
Aplikasi Model Peleg untuk Analisa Rehidrasi Tekwan Kering pada Beberapa Suhu Perendaman
}

\author{
Application of Peleg Model on Rehydration Analysis of Dried Tekwan at Various \\ Immersion Water Temperature \\ Marisa Tri Amanah, Universitas Sriwijaya. \\ Email: marisadamhir@yahoo.co.id \\ Hasbi, Universitas Sriwija ya. \\ Email: hasbi@unsri.ac.id \\ Ari Hayati, Universitas Sriwijaya. \\ Email: arihayati@unsri.ac.id
}

\begin{abstract}
This study was aimed to apply Peleg Model to analyze rehydration of dried tekwan at several variations of water immersion temperature. The method used was descriptive and experimental of one factor treatment (Non Factorial), which was immersion temperature with four treatments level $\left(30,45,70\right.$ and $\left.90^{\circ} \mathrm{C}\right)$, each treatment was done triplicate. The parameter observed was moisture content at times of observation. The result showed that the Peleg Model coefficients $\left(K_{1}\right.$ and $\left.K_{2}\right)$ were inversely affected by the temperature. The relationship was expressed into non-linear regression (polynomial) with $R^{2}$ value of 0,973 and 0,988. It showed that the obtained Peleg model could be applied adequately for the rehydration of dried tekwan at some immersion temperature. The resulting model also met the statistical criteria with the largest SEE and MRE values $6.73 \%$ and $3.58 \%$. The model could predict the dried tekwan rehydration best at the temperature of $30^{\circ} \mathrm{C}$ and $45^{\circ} \mathrm{C}$ with the smallest SEE and MRE values.
\end{abstract}

Keywords: Rehydration, Peleg Model, immersion temperature, tekwan

\begin{abstract}
Abstrak
Penelitian ini bertujuan untuk mengaplikasikan Model Peleg untuk analisa rehidrasi tekwan kering pada beberapa variasi suhu perendaman. Metode yang digunakan adalah deskriptif dan eksperimental satu faktor perlakuan (Non Faktorial), yaitu suhu perendaman dengan empat taraf perlakuan $\left(30,45,70\right.$ dan $\left.90^{\circ} \mathrm{C}\right)$, masing-masing perlakuan diulang sebanyak tiga kali. Parameter yang diamati yaitu kadar air tekwan kering selama waktu perendaman. Hasil penelitian menunjukkan koefisien Model Peleg (K1 dan K2) berbanding terbalik dengan suhu perendaman. Hubungan ini dinyatakan dalam regresi non linear (polinomial) dengan nilai $R^{2} 0.973$ dan 0.988 . Hasil tersebut menunjukkan bahwa model yang dihasilkan dapat diaplikasikan dengan baik untuk rehidrasi tekwan kering pada beberapa suhu perendaman. Model yang dihasilkan juga memenuhi kriteria statistik dengan nilai SEE dan MRE terbesar adalah $6.73 \%$ dan $3.58 \%$. Model dapat memprediksi rehidrasi tekwan kering terbaik pada suhu $30^{\circ} \mathrm{C}$ dan $45^{\circ} \mathrm{C}$ karena memiliki nilai SEE dan MRE terkecil.
\end{abstract}

Kata Kunci: rehidrasi, model Peleg, suhu perendaman, tekwan 


\section{Latar Belakang}

Tekwan hampir sama seperti pempek, yaitu produk pangan tradisional yang dapat digolongkan sebagai gel ikan dan merupakan produk yang bersifat basah sehingga umur simpannya relatif pendek. Sifat tekwan yang basah menyebabkan distribusinya terbatas dan sulit dijadikan oleh-oleh bagi wisatawan yang berdomisili di luar Provinsi Sumatera Selatan. Salah satu upaya yang dilakukan untuk memperpanjang umur simpan tekwan adalah dengan cara mengurangi kadar airnya sehingga menjadi produk yang kering. Namun, produk tekwan kering harus dilakukan rehidrasi melalui perendaman dan perebusan terlebih dahulu sebelum dapat dikonsumsi. Rehidrasi dilakukan agar produk tekwan kering dapat menyerap air hingga ke bagian dalam, sehingga produk tidak keras saat dikonsumsi. Rehidrasi tekwan kering biasanya dilakukan selama 4 sampai 12 jam. Rehidrasi yang dilakukan dalam waktu yang lama tersebut sangat memungkinkan produk tekwan terkontaminasi oleh bakteri, sehingga dapat mempengaruhi kualitas produk tekwan kering tersebut.

Rehidrasi merupakan upaya mengembalikan kandungan air pada bahan yang telah dikeringkan, umumnya dilakukan melalui proses perendaman dalam air. Lamanya waktu perendaman tergantung dari produk yang direhidrasi. Salah satu metode umum untuk mempersingkat waktu perendaman adalah dengan merendam dalam air hangat. Rehidrasi merupakan proses yang kompleks, dipengaruhi oleh banyak faktor antara lain, bentuk produk, suhu pengeringan dan suhu rehidrasinya (Garcia-Segovia et al. 2011). Oleh karena itu, model matematika penting dalam desain dan optimalisasi proses dehidrasi dan rehidrasi bidang industri pangan.

Salah satu model matematika yang dapat digunakan untuk optimalisasi proses rehidrasi bahan pangan adalah model Peleg. Model Peleg sudah berhasil diterapkan pada rehidrasi beberapa produk pangan, diantaranya jamur Morchella esculenta (Garcı'a-Pascual et al. 2006), kacangkacangan (Shafaei et al. 2016), Sharanagat et al. 2018)), nasi pratanak (Rafiq et al. 2015), dan daging asin (Munoz et al. 2012). Model Peleg banyak digunakan sebagai metode analisis data karena model yang dihasilkan lebih akurat dan mudah diterapkan. Model Peleg merupakan model yang dapat menggambarkan laju penyerapan air ke dalam bahan untuk tiap variasi suhu. Model Peleg dapat memberikan informasi profil penyerapan air dan kondisi maksimum penyerapan air ke dalam bahan. Selain itu, dari model yang dihasilkan akan dapat digunakan untuk memprediksi lama waktu perendaman yang baik untuk mencapai kadar air yang diinginkan.

\section{Bahan dan Metode}

\section{Bahan dan Alat}

Bahan yang digunakan adalah daging ikan Tenggiri yang sudah digiling, tepung tapioka, air bersih, garam halus. Peralatan yang digunakan adalah pengering kabinet (oven merek Memmert), neraca analitik (merek Ohaus), water bath (merek IKA ®HB 05.06 CN), thermometer.

\section{Pembuatan Tekwan Kering}

Pembuatan tekwan dengan formulasi 220 gram daging ikan tenggiri, $100 \mathrm{ml}$ air bersih, 10.5 gram garam halus $(2.5 \%$ dari total berat daging ikan dan tepung (Karneta 2013)) dan 200 gram tepung tapioka. Adonan tekwan ditimbang sebanyak 5 gram untuk satu sampel tekwan dan dibentuk. Tekwan yang sudah dibentuk direbus dalam air yang mendidih selama 2 menit hingga tekwan mengapung, kemudian ditiriskan dan dikeringanginkan. Tekwan dikeringkan menggunakan oven pada suhu $55^{\circ} \mathrm{C}$ selama 21 jam sampai mencapai kadar air sekitar 10\% (target kadar air berdasarkan Pratama et al. 2004).

\section{Rehidrasi Tekwan}

Rehidrasi dilakukan pada suhu perendaman yang terdiri dari empat taraf perlakuan, yaitu: $\mathrm{T} 1=30 \pm 2^{\circ} \mathrm{C}, \mathrm{T} 2=45 \pm 2^{\circ} \mathrm{C}, \mathrm{T} 3=70 \pm 2^{\circ} \mathrm{C}$, $\mathrm{T} 4=90 \pm 2^{\circ} \mathrm{C}$.

Suhu $45^{\circ} \mathrm{C}$ dipilih sebagai titik tengah pada interval suhu $0^{\circ} \mathrm{C}$ sampai dengan suhu tertinggi yang digunakan pada penelitian ini $\left(90^{\circ} \mathrm{C}\right)$. Setiap perlakuan diulang sebanyak tiga kali. Rehidrasi tekwan kering dilakukan berdasarkan metode Cunningham et al. (2007) yang telah dimodifikasi. Tekwan kering dipilih berdasarkan bentuk yang paling menyerupai dengan selisih berat, tebal dan diameter berkisar 0.1. Kadar air awal tekwan sudah diketahui (10.22\% bk). Water bath diisi dengan air bersih sampai batas yang dibutuhkan $( \pm 100 \mathrm{ml})$. Water bath disiapkan dengan mengatur suhu yang diinginkan $\left(45,70\right.$, dan $\left.90^{\circ} \mathrm{C}\right)$, khusus untuk suhu $30^{\circ} \mathrm{C}$ perendaman dilakukan di luar water bath. Gelas beaker yang sudah berisi $40 \mathrm{ml}$ air bersih dimasukkan ke dalam water bath. Tekwan kering dimasukkan ke dalam gelas beaker saat display suhu pada water bath sudah mencapai suhu yang diinginkan. Rehidrasi dilakukan selama 4 jam. Tekwan ditimbang tiap interval waktu rehidrasi 15 menit pada 2 jam perendaman pertama dan tiap 30 menit pada 2 jam terakhir. Data penambahan berat akan digunakan untuk perhitungan kadar air pada waktu t percobaan $\left(\mathrm{M}_{\mathrm{t}}\right)$.

\section{Analisis Data}

Data yang diperoleh diolah menggunakan metode regresi korelasional melalui software Microsoft Office Excel menggunakan persamaan model Peleg (Persamaan 1). 
$M t=M 0+\frac{\mathrm{t}}{(K 1-K 2)}$

Dimana Mt adalah kadar air pada saat t perendaman (\% bk), Mo adalah kadar air awal (\% bk), t waktu (jam), K1 Koefisien Peleg yang menyatakan parameter kinetik (jam\%-1), K2 Koefisien Peleg yang menyatakan parameter lain yang berhubungan dengan kadar air kesetimbangan ( $\left.\%{ }^{1} \mathrm{bk}\right)$.

Persamaan (1) dapat diliniearkan menjadi:

$\frac{t}{(M t-M o)}=K 1+K 2 t$

Persamaan (2) digunakan untuk mencari koefisien model Peleg (K1 dan K2) dan hubungannya dengan suhu dan waktu perendaman. Hubungan tersebut kemudian dinyatakan dengan koefisien determinasi (R2).

\section{Koefisien Model Peleg $\left(\mathrm{K}_{1}\right.$ dan $\left.\mathrm{K}_{2}\right)$}

Laju rehidrasi saat awal rehidrasi dimulai $\left(t=t_{0}\right)$ dapat dihitung dengan persamaan 3 .

$R 0=d M / d t t=0= \pm \frac{1}{K 1}$

Kadar air kesetimbangan saat $\mathrm{t}=\infty$ dapat dihitung dengan persamaan 4 .

$M e=M 0+\frac{1}{K 2}$

\section{Analisa Statistik}

Kelayakan suatu model matematika pada data percobaan dapat dievaluasi menggunakan koefisien determinasi $\left(R^{2}\right)$ (Solomon 2007), estimasi standar error (SEE) (Witrowa-Rajchert dan Lewicki 2006) dan rata-rata persen error (MRE) (Garcia-Pascual et al. 2006).
Tabel 1. Spesifikasi tekwan hasil penelitian.

\begin{tabular}{lcc}
\hline Spesifikasi & Tekwan Segar & Tekwan Kering \\
\hline Berat $(\mathrm{g})$ & 5.5977 & 2.5128 \\
Tebal $(\mathrm{cm})$ & 0.8 & 0.7 \\
Diameter $(\mathrm{cm})$ & 2.6 & 2.5 \\
Volume $\left(\mathrm{cm}^{3}\right)$ & 5 & 2 \\
Densitas $\left(\mathrm{g} / \mathrm{cm}^{3}\right)$ & 1.1275 & 1.2412 \\
Kadar air $(\% \mathrm{BB})$ & 62.03 & 9.27 \\
Kadar air $(\% \mathrm{BK})$ & 163.51 & 10.22 \\
\hline
\end{tabular}

$$
\begin{aligned}
& S E E=\left[\frac{\Sigma(X i, \exp -X p r e)^{2}}{\mathrm{df}}\right]^{0.5} \\
& M R E=\frac{100}{N} \Sigma\left[\frac{(X i, \exp -X i, \text { pre })}{X i, \exp }\right]
\end{aligned}
$$

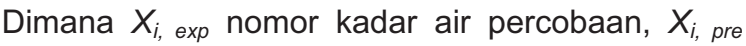
nomor kadar air prediksi, $\mathrm{N}$ nomor pengamatan

\section{Hasil dan Pembahasan}

\section{Spesifikasi Tekwan}

Kadar air tekwan kering yang dihasilkan dari proses pengeringan pada suhu $55^{\circ} \mathrm{C}$ selama 21 jam adalah $9.27 \%$ basis basah dan $10.22 \%$ basis kering . Spesifikasi tekwan hasil penelitian meliputi berat, tebal, diameter, volume, densitas, kadar air tekwan segar dan kadar air tekwan kering ditunjukkan pada Tabel 1

\section{Pengaruh Suhu terhadap Koefisien Model Peleg}

Model Peleg digunakan untuk mendapatkan persamaan linear rehidrasi tekwan kering pada setiap suhu perendaman $\left(30,45,70\right.$ dan $\left.90^{\circ} \mathrm{C}\right)$, sehingga dari persamaan tersebut didapat koefisien

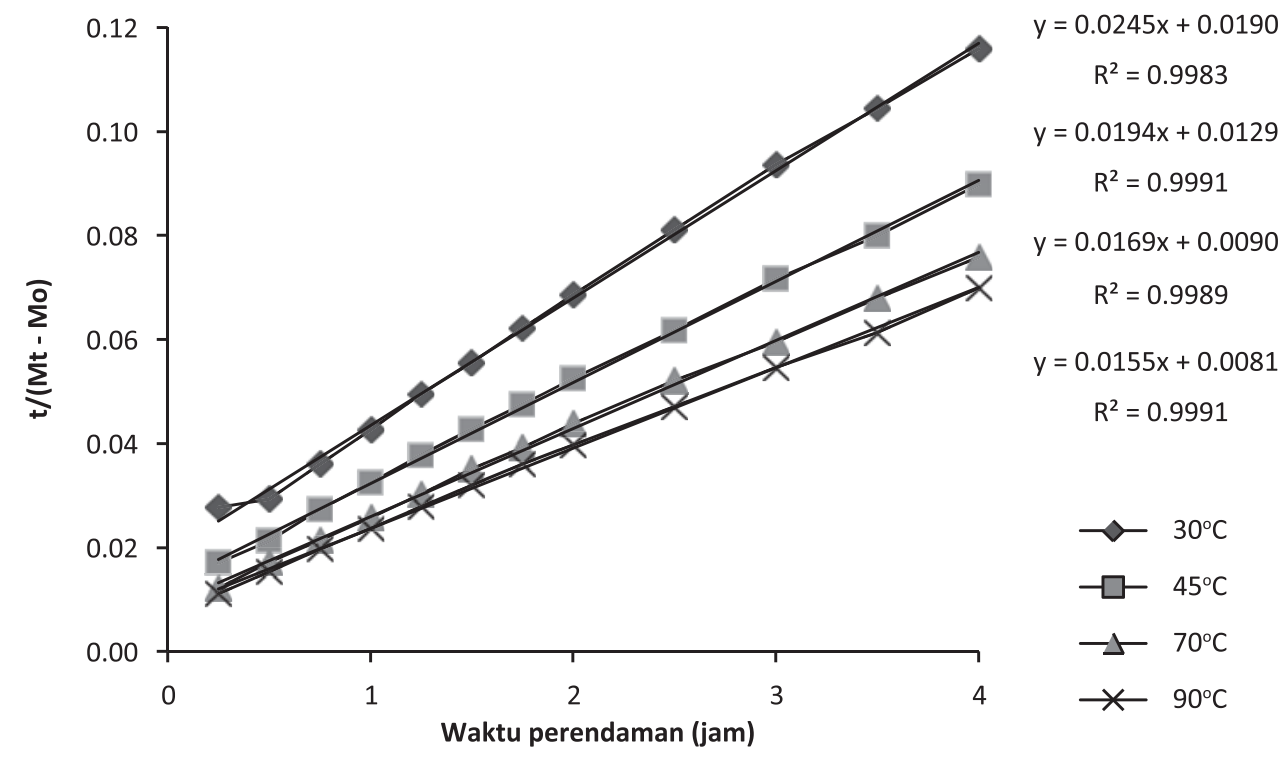

Gambar 1. Aplikasi model Peleg untuk rehidrasi tekwan kering pada suhu 30, 45, 70 dan $90^{\circ} \mathrm{C}$. 
Tabel 2. Pengaruh suhu terhadap koefisien Peleg (K1 dan K2).

\begin{tabular}{cccccc}
\hline Suhu $\left({ }^{\circ} \mathrm{C}\right)$ & Model Rehidrasi & $\mathrm{R}^{2}$ & $\mathrm{~K} 1\left(\mathrm{~h} \%^{-1}\right)$ & $\mathrm{K} 2\left(\%^{-1}\right)$ & $\mathrm{Me}(\% \mathrm{bk})$ \\
\hline 30 & $\mathrm{y}=0.024 \mathrm{x}+0.019$ & 0.998 & 0.019 & 0.024 & 52 \\
45 & $\mathrm{y}=0.019 \mathrm{x}+0.012$ & 0.999 & 0.012 & 0.019 & 63 \\
70 & $\mathrm{y}=0.016 \mathrm{x}+0.009$ & 0.998 & 0.009 & 0.016 & 73 \\
90 & $\mathrm{y}=0.015 \mathrm{x}+0.008$ & 0.999 & 0.008 & 0.015 & 77 \\
\hline
\end{tabular}

Peleg (K1 dan K2) pada setiap suhu perendaman. Persamaan linear rehidrasi tekwan kering pada suhu perendaman $30,45,70$ dan $90^{\circ} \mathrm{C}$ ditampilkan pada Gambar 1, sedangkan koefisien K1 dan K2 ditunjukkan pada Tabel 2.

Tabel 2 menunjukkan adanya pengaruh suhu terhadap koefisien Peleg (K1 dan K2) yang dinyatakan dengan koefisien determinasi antara 0.998 dan 0.999 . Besarnya nilai koefisien determinasi menunjukkan bahwa persamaan yang dihasilkan pada tiap suhu dapat menggambarkan rehidrasi tekwan kering dengan baik. Nilai K1 (Tabel 2) mengalami penurunan seiring dengan kenaikan suhu. Hasil ini sesuai dengan rehidrasi biji-bijian dimana nilai koefisien Peleg K1 berbanding terbalik dengan suhu perendaman. Penurunan nilai K1 pada suhu perendaman yang lebih tinggi menunjukkan air yang berpindah ke dalam bahan lebih banyak dibandingkan pada suhu yang lebih rendah. Hal ini dapat disebabkan karena semakin banyak pori-pori yang terbuka pada permukaan bahan akibat terjadinya gelatinisasi atau pengembangan permukaan bahan, ditandai dengan permukaan bahan yang semakin lembut (Shafaei et al. 2016; Sabrina et al. 2012).

Koefisien K2 pada model Peleg berhubungan dengan kapasitas maksimum rehidrasi atau kadar air kesetimbangan yang dapat dicapai pada rehidrasi. Semakin kecil nilai K2 menunjukkan jumlah air maksimum yang dapat diserap tekwan semakin besar. Nilai K2 (Tabel 2) rehidrasi tekwan kering berbanding terbalik dengan suhu perendaman. Nilai K2 menurun, yang berarti semakin tinggi kadar air maksimum yang mampu dicapai, seiring dengan peningkatan suhu perendaman. Namun, pada batas tertentu suhu yang terlalu tinggi dapat menyebabkan kerusakan pada struktur bahan yang dapat menghambat penyerapan air, seperti pada rehidrasi jamur kering (Hernando et al. 2008).

Data koefisien $\mathrm{K} 1$ dan $\mathrm{K} 2$ pada masing-masing suhu perendaman digunakan untuk menentukan persamaan umum pada rehidrasi tekwan kering dengan melihat hubungan koefisien tersebut terhadap suhu perendaman. Pengaruh suhu perendaman terhadap koefisien Peleg (K1 dan K2) ditunjukkan pada Gambar 2.

Persamaan yang dihasilkan dari regresi koefisien Peleg $\left(\mathrm{K}_{1}\right.$ dan $\left.\mathrm{K}_{2}\right)$ dan suhu (Gambar 2) digunakan untuk mendapatkan persamaan umum untuk rehidrasi tekwan kering. Berdasarkan persamaan Peleg, persamaan untuk model rehidrasi tekwan kering pada beberapa suhu perendaman mengikuti persamaan 7.

$$
M_{t}=M_{o}+\frac{t}{\left(0.000004 T^{2}-0.0007 \mathrm{~T}+0.035\right)+\left(0.000003 T^{2}-0.0005 T+0.036\right) t}(7)
$$

Dimana Mt kadar air saat t perendaman (\% bk), Mo kadar air awal sebelum rehidrasi (\% bk), t waktu

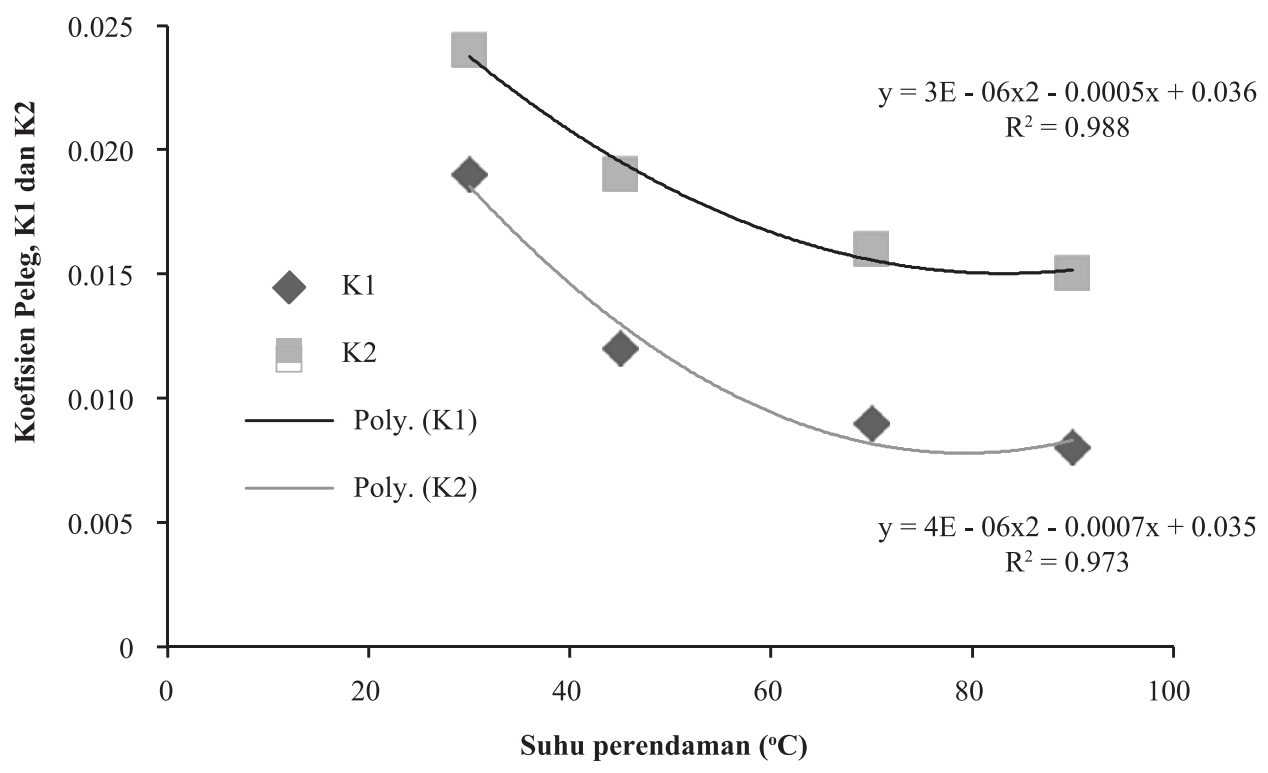

Gambar 2. Pengaruh suhu terhadap koefisien Peleg K1 dan K2 pada rehidrasi tekwan kering. 
perendaman (jam), $\mathrm{T}$ suhu perendaman $\left({ }^{\circ} \mathrm{C}\right), \mathrm{K}_{1}$ adalah $0.000004 \mathrm{~T}^{2}-0.0007 \mathrm{~T}+0.035, \mathrm{~K}_{2}$ adalah $0.000003 T^{2}-0.0005 T+0.036$

Gambar 2 menunjukkan koefisien determinasi pada $\mathrm{K}_{1}$ dan $\mathrm{K}_{2}$ masing-masing adalah 0.973 dan 0.988 . Nilai tersebut sudah cukup baik untuk kriteria permodelan rehidrasi. Hubungan antara variabel $X$ (waktu) dan Y (koefisien model Peleg) dinyatakan dalam regresi non linear (polinomial) karena memiliki nilai koefisien determinasi lebih besar dari regresi linear. Hubungan non-linear juga ditemukan pada rehidrasi irisan labu yang dikeringkan dengan metode swell-drying dan feeze-drying (Benseddik et al. 2018). Namun, berbeda dengan rehidrasi pada pasta yang menyatakan hubungan linear antara variabel $X$ dan $Y$ (Cunningham et al. 2007). Perbedaan ini diduga disebabkan dari perbedaan kandungan bahan, perbedaan struktur jaringan, komposisi kimia, dan adanya pengaruh variabel lain yang belum dimasukkan sebagai pertimbangan dalam menyusun model regresinya, antara lain adanya bahan kering yang terlarut selama perendaman terutama pada suhu perendaman yang lebih tinggi.

\section{Evaluasi Model Peleg pada Rehidrasi Tekwan Kering}

Rehidrasi pada produk-produk pangan dapat dianalisa menggunakan data perubahan kadar air (perbandingan massa air terhadap massa bahan kering) dan waktu rehidrasi (Markowski dan
Zielinska 2011). Selama 4 jam perendaman, kadar air tekwan tertinggi dihasilkan dari perendaman pada suhu tertinggi $\left(90^{\circ} \mathrm{C}\right)$ sedangkan kadar air terendah dihasilkan dari perendaman pada suhu terendah $\left(30^{\circ} \mathrm{C}\right)$. Perubahan kadar air tekwan kering (Mt) selama perendaman pada suhu 30,45 , 70 dan $90^{\circ} \mathrm{C}$ ditunjukkan pada Gambar 3.

Penyerapan air pada masing-masing suhu perendaman meningkat tajam pada awal rehidrasi yaitu selama satu jam perendaman pertama dan cenderung stabil pada tiga jam terakhir. Hal ini merupakan fenomena umum dalam rehidrasi, dimana terdapat dua fase, yaitu fase difusi dan relaksasi (Sharanagat et al. 2018). Selain itu, kecepatan rehidrasi dipengaruhi oleh struktur bahan yang dapat dipengaruhi oleh proses yang dialami oleh bahan sebelum direhidrasi, salah satunya proses pengeringan (Vergeldt et al. 2014). Fase difusi terjadi saat awal rehidrasi, dimana perbedaan kandungan air antara tekwan kering dan air perendaman sangat besar. Perbedaan ini menjadi daya dorong air masuk ke dalam bahan. Semakin besar perbedaan kadar airnya, maka semakin besar pula daya dorong air masuk ke dalam tekwan kering. Semakin tinggi suhu perendaman maka semakin banyak air yang diserap tekwan kering.

Persamaan model Peleg yang didapatkan digunakan untuk memprediksi kadar air tekwan kering selama interval waktu dan suhu perendaman. Hasil prediksi model Peleg ditampilkan pada Tabel 3.

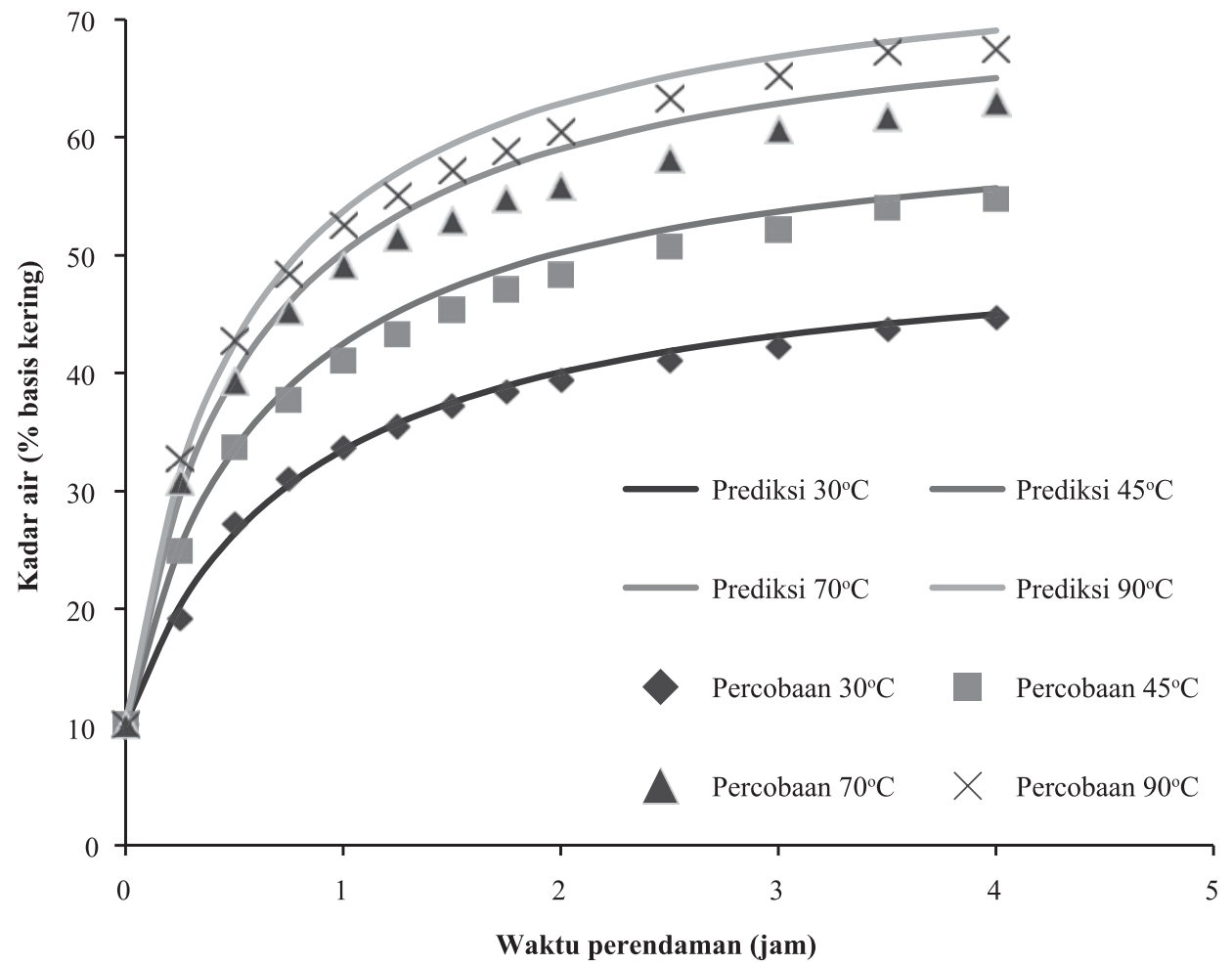

Gambar 3. Data percobaan dan prediksi (Model Peleg) kadar air tekwan kering hasil rehidrasi pada suhu $30,45,70$ dan $90^{\circ} \mathrm{C}$ 
Tabel 3. Prediksi Koefisien Peleg $\left(\mathrm{K}_{1}\right.$ dan $\left.\mathrm{K}_{2}\right)$, kadar air kesetimbangan $(\mathrm{Me})$, SEE dan MRE pada rehidrasi tekwan kering.

\begin{tabular}{cccccc}
\hline Suhu $\left({ }^{\circ} \mathrm{C}\right)$ & K1 (h\%-1) & K2 (\%-1) & Me $(\%$ BK) & SEE (\%) & MRE $(\%)$ \\
\hline 30 & 0.018 & 0.024 & 51.72 & 0.99 & 0.84 \\
45 & 0.012 & 0.020 & 60.28 & 0.66 & 0.38 \\
70 & 0.006 & 0.016 & 72.33 & 6.73 & 3.58 \\
90 & 0.005 & 0.016 & 73.92 & 4.66 & 2.60 \\
\hline
\end{tabular}

Nilai SEE dan MRE (Tabel 3) terkecil adalah pada suhu perendaman $45^{\circ} \mathrm{C}$ dan semua nilai MRE pada keempat suhu perendaman tersebut di bawah $10 \%$. Hasil ini menyatakan bahwa variabel yang digunakan dapat memprediksi kadar air sesuai dengan data hasil percobaan, namun persamaan yang diusulkan dapat lebih baik pada data percobaan suhu rendah berkisar $30-45^{\circ} \mathrm{C}$ (Gambar 3). Hal ini sejalan dengan hasil rehidrasi pada pasta, yaitu persamaan terbaik pada data percobaan $20-60^{\circ} \mathrm{C}$ (Cunningham et al. 2007).

Gambar 3 mengilustrasikan data rehidrasi berdasarkan prediksi dan hasil percobaan dengan menghubungkan hasil analisis statistik (SEE dan MRE) yang ditampilkan pada Tabel 3. Gambar tersebut menegaskan bahwa model yang dihasilkan dapat menggambarkan data prediksi yang lebih tepat dengan data hasil percobaan pada suhu perendaman yang rendah $\left(30-45^{\circ} \mathrm{C}\right)$ dibandingkan pada suhu yang lebih tinggi $\left(70\right.$ dan $\left.90^{\circ} \mathrm{C}\right)$. Hal ini dapat terjadi karena adanya kompleksitas reaksi yang terjadi pada bahan yang disebabkan suhu tinggi seperti pelarutan zat padat, denaturasi protein dan perubahan struktur permukaan bahan. Hal ini dapat dipengaruhi oleh sifat dan karakteristik bahan yang direhidrasi.

\section{Simpulan}

Suhu perendaman berpengaruh terhadap rehidrasi tekwan kering. Koefisien model Peleg K1 dan K2 dipengaruhi oleh suhu perendaman. Nilai K1 dan K2 menurun pada suhu perendaman yang lebih tinggi menandakan peningkatan laju absorbsi saat awal rehidrasi dan peningkatan kadar air kesetimbangan. Model Peleg dapat digunakan dengan tepat untuk memprediksi rehidrasi tekwan kering terutama pada suhu perendaman yang lebih rendah $30^{\circ} \mathrm{C}$ dan $45^{\circ} \mathrm{C}$ dengan nilai SEE dan MRE yang lebih rendah dibandingkan pada suhu yang lebih tinggi $70^{\circ} \mathrm{C}$ dan $90^{\circ} \mathrm{C}$. Perlu dilakukan analisa mendalam tentang parameter Peleg (K1 dan K2) untuk mendapatkan rancangan rehidrasi tekwan kering yang lebih efektif.

\section{Daftar Pustaka}

Benseddik, A., A. Azzi, M.N. Zidoune, R. Khanniche, C. Besombes. 2018. Empirical and diffusion models of rehydration process of differently dried pumpkin slices. Journal of the Saudi Society of Agricultural Sciences, https://doi.org/10.1016/j. jssas.2018.01.003

Cunningham, S.E., W.A.M. McMinn, T.R.A. Magee, dan P.S. Richardson. 2007. Modelling Water Absorption of Pasta during Soaking. J. Food Eng., 82: 600-607

Garci'a-Pascual, P., N. Sanju'an, R. Melis, A. Mulet. 2006. Morchella esculenta (morel) rehydration process modelling. Journal of Food Engineering 72: 346-353

García-Segovia, P., A. Andrés-Bello, J. MartínezMonzó. 2011. Rehydration of air-dried Shiitake mushroom (Lentinus edodes) caps: Comparison of conventional and vacuum water immersion processes. LWT - Food Science and Technology 44 (2): 480-488

Hernando, I., N. Sanju'an, I. P'erez-Munuera, A. Mulet. 2008. Rehydration of FreezeDried and Convective Dried Boletusedulis Mushrooms:Effect on Some Quality Parameters. Journal of Food Science 73(8): 356-362

Karneta, R. 2013. Difusivitas Panas dan Umur Simpan Pempek Lenjer. J. Keteknikan Pertanian. 1 (1): 131-141

Markowski, M. dan M. Zielinska. 2011. Kinetics of Water Absorption and Soluble-Solid Loss of Hot air dried Carrots during Rehydration. Int. J. Food Sci. Tech. 46 : 1122-1128.

Muñoz, I., N. Garcia-Gil, J. Arnau, P. Gou. 2012. Rehydration kinetics at 5 and $150 C$ of dry salted meat. Journal of Food Engineering 110: 465-471

Pratama, F., K. Yuliati, dan I. Oktarina. 2004. Tekwan Kering Cepat Saji dan Metode Pembuatannya dengan Aplikasi Pembekuan. Nomor Paten: P00200300567.Universitas Sriwijaya. Palembang.

Rafiq, A., J. Chowdhary, M.K. Hazarika, H.A. Makroo. 2015. Temperature dependence on hydration kinetic model parameters during rehydration of parboiled rice. J Food Sci Technol 52(9):6090-6094, doi: 10.1007/s13197-015$1790-7$ 
Sabrina, C., S. Gupta, N. Abu-Ghannam. 2012. Effect of different rehydration temperatures on the moisture, content of phenolic compounds, antioxidant capacity and textural properties of edible Irish brown seaweed. LWT - Food Science and Technology 47: 300-307

Shafaei, S.M., A.A. Masoumi, H. Roshan. 2016. Analysis of water absorption of bean and chickpea during soaking using Peleg model. Journal of the Saudi Society of Agricultural Sciences 15: 135-144

Sharanagat, V.S., V. Kansal, K. Kumar. 2018. Modeling the effect of temperature on the hydration kinetic whole moong grain. Journal of the Saudi Society of Agricultural Sciences Vol 17: $268-274$
Solomon, W.K. 2007. Hydration kinetics of lupin (lupinus albus) seeds. J. Food Process and Engineering. 30: 119-130.

Vergeldt, F.J., G. van Dalen, A.J. Duijster, A. Voda, S. Khalloufi, L.J. van Vliet, H. van As, J.P.M. van Duynhoven, R.G.M. van der Sman. 2014. Rehydration kinetics of freeze-dried carrots. Innovative Food Science and Emerging Technologies, http://dx.doi.org/10.1016/j. ifset.2013.12.002

Witrowa-Rajchert, D., dan P.P. Lewicki. 2006. Rehydration properties of dried plant tissues. $J$. Science and Technology. 41: 1040-1046. 
Halaman ini sengaja dikosongkan 


\section{Indeks Penulis}

Jurnal Keteknikan Pertanian Volume 8 Tahun 2020

Abdullah bin Arif, 29

Ahmuhardi Abdul Azis, 45

Andi Ani Kuswati, 15

Ari Hayati, 81

Armansyah Halomoan Tambunan, 39, 53, 89

Bambang Pramudya, 63

Budi Santoso, 113

Dadan Kusdiana, 39

Darma, 113

Desrial, 89

Dwi Zuwarman, 1

Edy Hartulistiyoso, 39, 53

Emmy Darmawati, 15, 63, 97, 105

Evi Savitri Iriani, 71

Fajar Kurniawan, 71

Hasbi, 81

Hendri Syah, 53

Herbert Hasudungan Siahaan, 89

I Dewa Made Subrata, 9

I Wayan Budiastra, 45

Inge Scorpi Tulliza, 39
Lamhot Parulian Manalu, 53

Marisa Tri Amanah, 81

Nafilawati Wa Ode, 97

Nurul Khumaida, 97

Reniana, 113

Riska Juliana, 23

Rismen Sinambela, 9

Rokhani Hasbullah, 1, 23

Sandro Pangidoan Siahaan, 29

Sari Intan Kailaku, 29

Soni Solistia Wirawan, 89

Siti Mariana Widayanti, 15

Sri Lestari, 71

Sutrisno Suro Mardjan, 1, 23, 45, 63, 97, 105

Syamsul Bahri, 63

Tatang Hidayat, 29

Tineke Mandang, 9

Usman Ahmad, 71

Wawan Hermawan, 9

Yandri Iskandar Pah, 105 


\section{Indeks Subjek}

Jurnal Keteknikan Pertanian Volume 8 Tahun 2020

ASLT Method, 23

Biodiesel, 39

Biogas, 89

Catalyst, 39

Curing, 29

Cylinder type, 113

Distribution centers, 63

Dormancy, 29

Drying model, 53

Drying rate, 53

Edible coating, 105

Energy ratio, 39

Engine performance, 89

Expiration date, 23

Exposure duration, 15

Extraction, 45

Fresh Fruit Bunch, 9

Genotipe, 97

Good Handling Practices, 1

Good Manufacturing Practices, 1

Growth power, 29

Hellical barrier, 89
Immersion temperature, 81

Irradiation, 71

Moisture sorption isotherm, 23

Oil palm, 9

Oleoresin, 45

Optimum Ripeness Position, 9

Ozon, 15

Peleg model, 81

Physicoshemical, 97

Rasping performance, 113

Rehydration, 81

Rice Milling Unit, 1

Rotation speed, 113

Static mixer reactor, 39

Storage, 29, 71

Teeth diameter, 113

Temperature, 29

Thin layer drying, 53

Total Plate Count, 15

Ultrasound, 45

Yield, 45 